\title{
UPAYA MENINGKATKAN KEDISIPLINAN GURU DALAM \\ KEHADIRAN MENGAJAR MELALUI REWARD AND PUNISHMENT DI SMP NEGERI 1 KECAMATAN PAYAKUMBUH SEMESTER 2 TAHUN PELAJARAN 2018/2019
}

\author{
Ahmad Guntur \\ SMP Negeri 1 Kecamatan Payakumbuh, Kabupaten Lima Puluh Kota \\ email: ahmadguntur1965@yahoo.com
}

\begin{abstract}
A disciplined teacher is very much needed to give birth to the next generation of knowledgeable people and good personalities. In order for teacher discipline in teaching, rewards and punishments are held. The problem studied in this study is whether through reward and punishment by the principal can improve teacher discipline in teaching attendance at SMP Negeri 1 Payakumbuh Subdistrict Semester 2 in the 2018/2019 academic year? The purpose of this study was to examine the implementation of reward and punishment by the principal to improve teacher discipline in teaching attendance at SMP Negeri 1 Payakumbuh Subdistrict, Semester 2, 2018/2019 Academic Year. This research is a classroom action research and was carried out in two cycles. Each cycle is carried out in two meetings. The stages of each cycle are planning, implementing, observing, and reflecting. The subjects in this study were 44 ASN teachers at SMP Negeri 1 Payakumbuh District. This research was conducted from 25 May to 10 June 2019. Based on data analysis, it is known that there has been an increase in teacher discipline in teaching attendance through reward and punishment at SMP Negeri 1 Payakumbuh Subdistrict in semester 2 of the 2018/2019 academic year.
\end{abstract}

Keywords: Discipline, Reward, Punishment

\begin{abstract}
ABSTRAK
Guru yang disiplin sangat diperlukan untuk melahirkan generasi penerus bangsa yang berilmu pengetahuan dan berkepribadian yang baik. Agar kedisiplinan guru dalam mengajar, maka diadakannya pemberian reward and punishmen. Masalah yang dikaji dalam penelitian ini adalah apakah melalui reward and punishment oleh kepala sekolah dapat meningkatkan kedisiplinan guru dalam kehadiran mengajar di SMP Negeri 1 Kecamatan Payakumbuh Semester 2 Tahun Pelajaran 2018/2019? Tujuan dari penelitian ini adalah untuk mengkaji pelaksanan reward and punishment oleh kepala sekolah untuk meningkatkan kedisiplinan guru dalam kehadiran mengajar di SMP Negeri 1 Kecamatan Payakumbuh Semester 2 Tahun Pelajaran 2018/2019. Penelitian ini merupakan penelitian tindakan kelas dan dilaksanakan sebanyak dua siklus. Masing-masing siklus dilaksanakan dalam dua kali pertemuan. Tahapan setiap siklus adalah perencanaan, pelaksanaan, pengamatan, dan refleksi. Subyek pada penelitian ini adalah guru di SMP Negeri 1 Kecamatan Payakumbuh sebanyak 44 orang ASN. Penelitian ini dilaksanakan dari 25 Mei sampai 10 Juni 2019. Berdasarkan analisis data diketahui bahwa terjadi peningkatan kedisiplinan guru dalam kehadiran mengajar melalui reward and punishment di SMP Negeri 1 Kecamatan Payakumbuh semester 2 tahun pelajaran 2018/2019.
\end{abstract}

Kata Kunci: Kedisiplinan, Reward, Punishment 


\section{PENDAHULUAN}

Kedisiplinan guru sangatlah perlu diperhatikan, karena guru merupakan sebuah pekerjaan untuk melahirkan generasi penerus bangsa yang berilmu pengetahuan dan berkepribadian yang baik. Apabila kedisiplinan guru tidak diperhatikan maka tujuan pengajaranpun tidak akan optimal. Banyak sekali faktor yang dapat mempengaruhi tingkat kedisiplinan guru, salah satunya adalah kepala sekolah. ketegasan dan konsisten kepala sekolah sangat mempengaruhi kedisiplinan guru. Jika kepala sekolah konsisten dan juga tegas dalam menerapkan peraturan, maka keiinginan guru untuk berprilaku indispiner akan mengurang.

Peningkatan disiplin guru utamanya dimulai dari sekolah. Pada lingkungan sekolah, posisi kepala sekolah sebagai sumber team leader atau manajer sekolah sangat penting perannya melalui upaya yang direncanakan secara efektif dan efisien, baik buruknya kualitas disiplin guru pada suatu sekolah erat kaitannya dengan usaha atau upaya kepemimpinan kepala sekolah dalam mengendalikan, memacu dan meningkatkan segala potensi, dan praturan yang ada sebagai salah satu fungsi manajemen. Wantah (2005:140) menyatakan bahwa disiplin adalah "suatu cara untuk membantu anak agar dapat mengembangkan pengendalan diri". Sedangkan menurut Prijodarminto (1993:23) "disiplin adalah suatu kondisi yang tercipta dan terbentuk melalui proses dari serangkaian prilaku yang menunjukkan nilai-nilai tersebut telah menjadi bagian perilaku dalam kehidupannya”.

Peningkatan disiplin guru tidak begitu saja lepas dari peranan dan usaha kepala sekolah. dalam menjalankan tugas pokok dan fungsinya kepala sekolah sedemikian rupa sehingga kondisi dan hasil pembelajaran dapat tercapai sesuai dengan tujuan yang hendak dicapai. Salah satu usaha atau upaya menciptakan kondisi diatas adalah dengan terus mengusahakan dan mengupayakan peningkatan disiplin guru.

Agar guru kedisiplinan dalam mengajar, maka diadakannya pemberian reward. Dengan diadakannya pemberian reward diharapkan untuk adanya peningkatan kinerja guru. Pemberian reward kepada guru merupakan penerapan pemberian motivasi ekstrinsik. "Motivasi ekstrinsik adalah motif-motif yang aktif dan berfungsinya karena adanya rangsangan dari luar" (Sardiman A.M, 2012: 90)

Reward merupakan metode yang memiliki prinsip penting pada teori-teori perilaku yang disebut dengan istilah reinforser. Prinsip yang paling penting pada teori-teori perilaku ialah perilaku berubah menurut konsekuensi langsung. Konsekuensi langsung yakni konsekuensi-konsekuensi yang menyenangkan atau memperkuat perilaku yang bersifat positif. Memperkuat perilaku dapat dilakukan dengan cara memberi pujian, pemberian hadiah, pemberian angka, dan pemberian bintang (Dahar, 2011: 20).

Sedangkan punishment atau hukuman adalah suatu sanksi yang diterima oleh seseorang sebagai akibat dari pelanggaran atau atas aturan-aturan yang telah ditetapkan. Hukuman diberikan sebagai alat pendidikan dimana hukuman yang diberikan harus dapat mendidik dan menyadarkan orang tersebut (Imron, 2012: 169). Ahmadi dan Uhbiyati (1991: 150) menjelaskan hukuman adalah suatu perbuatan, dimana kita sadar, dan sengaja menjatuhkan nestapa kepada orang lain, yang baik dari segi kejasmanian maupun dari segi kerohanian orang lain itu mempunyai kelamahan bila dibandingkan dengan diri kita, dan oleh karena itu 
maka kita mempunyai tanggung jawab untuk membimbingnya dan melindunginya.

Reward and Punisment diartikan sebagai pemberian penghargaan dan hukuman, penghargaan disini bukan hanya penghargan dalam bentuk materi saja termasuk di dalamnya adalah pujian kepada guru yang dipandang disiplin dalam kehadiran di kelas pada kegiatan belajar-mengajar dan teguran atau hukuman kepada guru yang sering terlambat masuk kelas. Dari uraian tersebut menunjukkan bahwa salah satu upaya untuk membina kedisiplinan guru dalam kehadiran mengajar adalah melalui reward and punishment yang dilakukan oleh kepala sekolah.

\section{METODOLOGI}

Penelitian tindakan sekolah ini dilaksanakan di SMP Negeri 1 Kecamatan Payakumbuh pada semester 2 tahun pelajaran 2018/2019. Pada tahun itu banyak hasil penelitian yang kurang mengarah pada peningkatan mutu pendidikan. Peneliti mengambil tempat penelitian di SMP Negeri 1 Kecamatan Payakumbuh karena SMP ini merupakan SMP tempat bertugas Peneliti. Subyek pada penelitian ini adalah guru di SMP Negeri 1 Kecamatan Payakumbuh sebanyak 44 orang terdiri dari 42 ASN dan 2 Honorer. Penelitian yang berhubungan dengan penggunaan upaya meningkatkan kedisiplinan guru dalam kehadiran mengajar melalui reward and punishment di SMP Negeri 1 Kecamatan Payakumbuh Semester 2 Tahun Pelajaran 2018/2019 dilaksanakan dari 25 Mei sampai 10 Juni 2019.

Teknik pengumpulan data pada penelitian ini terdiri atas tiga kegiatan pokok yakni pengumpulan data awal, data hasil analisis setiap akhir siklus, serta tanggapan lain dari guru terhadap pelaksanaan reward and punishment. Data yang telah dikumpulkan dianalisis dengan menggunakan analisis kualitatif dan kuantitatif. Analisis kualitatif digunakan untuk menjelaskan perubahan kedisiplinan guru dalam kehadiran mengajar melalui reward and punishment guru.

\section{HASIL PENELITIAN DAN PEMBAHASAN}

\section{Hasil Penelitian}

\section{Siklus I}

\section{a. Perencanaan Siklus I}

Dalam melaksanakan penelitian tindakan sekolah yang difokuskan kepada pelaksanaan reward and punishment oleh kepala sekolah di SMP Negeri 1 Kecamatan Payakumbuh, peneliti terlebih dahulu menyusun rencana tindakan. Rencana tindakan yang disusun untuk siklus pertama adalah :

1. Merumuskan masalah yang akan dicari solusinya. Dalam penelitian ini masalah yang akan dicari solusinya adalah masih banyaknya guru yang kurang disiplin dalam kehadiran dikelas pada proses belajar mengajar

2. Merumusan tujuan penyelesaian masalah/tujuan menghadapi tantangan/tujuan melakukan inovasi/tindakan. Dalam penelitian ini penulis mengambil rencana untuk melakukan tindakan memberikan Reward dan Punishment kepada guruguru untuk meningkatkan kedisiplinan guru dalam kehadiran dikelas pada proses belajar mengajar. 
3. Merumusan indikator keberhasilan penerapan Reward dan Punishment dalam meningkatkan disiplin guru dalam kehadiran dikelas pada proses belajar mengajar. Indikator keberhasilan penerapan tindakan ini penulis tetapkan sebesar $75 \%$, artinya tindakan ini dinyatakan berhasil bila $75 \%$ guru tidak terlambat masuk kelas dalam proses pembelajaran.

4. Merumusan langkah-langkah kegiatan penyelesaian masalah/kegiatan menghadapi tantangan/kegiatan melakukan tindakan.Langkah-langkah yang diambil penulis dalam melakukan tindakan antara lain adalah melakukan sosialisasi kepada para guru mengenai penelitian yang akan dilaksanakan, serta menyampaikan tujuan dari penerapan tindakan yang dilakukan oleh penulis.

5. Merancang pelaksanaan siklus pertama ini meliputi penentuan waktu untuk observasi terhadap kegiatan reward and punishment guru dalam pelaksanaan pembelajaran.

6. Menyusun alat pengamatan yang akan digunakan untuk melihat aktivitas guru dalam pelaksanaan pembelajaran melalui reward and punishment oleh kepala sekolah.

7. Melakukan pengamatan aktivitas guru dalam pelaksanaan pembelajaran melalui reward and punishment oleh kepala sekolah.

8. Melakukan diskusi dengan kolaborator berdasarkan hasil pengamatannya, sehingga menjadi bahan perbaikan atau refleksi bagi guru.

\section{b. Tindakan Siklus I}

Siklus pertama dilaksanakan pada hari Senin tanggal 3 Juni 2019 yang dimulai pada pukul 07.30-08.40 WIB. Tempat pelaksanaan kegiatan di SMP Negeri 1 Kecamatan Payakumbuh. Dalam siklus pertama, kepala sekolah melaksanakan kegiatan reward and punishment untuk meningkatkan kedisiplinan guru dalam mengajar.

1) Menyebarkan lembar pengamatan kepada setiap Ketua Kelas atau Sekretaris kelas sebanyak 19 set, sesuai dengan banyaknya jumlah rombongan belajar di SMP .Negeri 1 Kadipaten sebanyak 19 rombongan belajar. Dalam lembar pengamatan itu, telah dibuat daftar guru yang mengajar dikelas itu setiap jam dan diberi kolom jam masuk kelas serta jam keluar kelas.

2) Berkoordinasi dengan petugas piket yang setiap hari terdiri dari 2 orang petugas, yaitu dari guru yang tidak mempunyai jam mengajar pada hari itu dan satu orang dari tata usaha. Petugas piket akan mengedarkan daftar hadir guru dikelas yang telah dibuat agar dapat melihat tingkat kehadiran guru disetiap kelas dan disetiap pergantian jam pelajaran. Guru yang terlambat lebih dari 15 menit, dianggap tidak hadir dan diberi tanda silang.

3) Setelah selesai jam pelajaran, dilakukan rekapitulasi dari hasil pengamatan, baik dari guru piket, dari siswa maupun dari penulis.

Kegiatan tersebut dilakukan terus setiap hari kepada setiap guru selama satu minggu (satu siklus).

\section{c. Observasi Siklus I}

Pengamatan atau observasi dilakukan oleh peneliti dengan menggunakan lembar observasi selama satu minggu (satu siklus), untuk semua guru yang berjumlah 44 orang. Selama pengamatan peneliti dibantu atau berkolaborasi dengan guru observer. Pengamatan oleh peneliti meliputi :

1) Kehadiran guru dikelas 
2) Tingkat keterlambatan guru masuk kelas

3) Waktu meninggalkan kelas setelah selesai pelajaran

4) Kerapian berseragam guru, dan kesiapan guru dalam memberikan materi ajar.

5) Kesiapan guru-guru untuk mentaati aturan tata tertib sekolah

6) Hasil akhir kerja

Peneliti juga melakukan penilaian dari hasil lembar observasi yang dibagikan kepada pengurus kelas untuk mengamati kehadiran guru dikelas. Dari hasil pengamatan serta rekap dari tingkat kehadiran guru dikelas pada proses belajar mengajar dapat dilihat pada tabel berikut :

Tabel 1. Rekapitulasi Tingkat Keterlambatan Guru Pada Kehadiran Di Kelas Siklus I

\begin{tabular}{|c|c|c|}
\hline \multicolumn{3}{|c|}{ Waktu Keterlambatan/Jumlah/Persentase } \\
\hline Kurang dari 10 menit & $\mathbf{1 0}$ menit s/d 15 menit & Lebih dari 15 menit \\
\hline 5 & 7 & 11 \\
\hline $22,73 \%$ & $30,82 \%$ & $45,46 \%$ \\
\hline
\end{tabular}

Dari hasil rekapitulasi tingkat keterlambatan guru dikelas pada proses pembelajaran diperoleh data, sebanyak 5 orang guru terlambat masuk kelas kurang dari 10 menit, 7 orang guru terlambat masuk kelas 10 menit sampai dengan 15 menit, dan 10 orang guru terlambat masuk kelas lebih dari 15 menit. Untuk lebih jelasnya dapat digambarkan pada grafik dibawah ini :

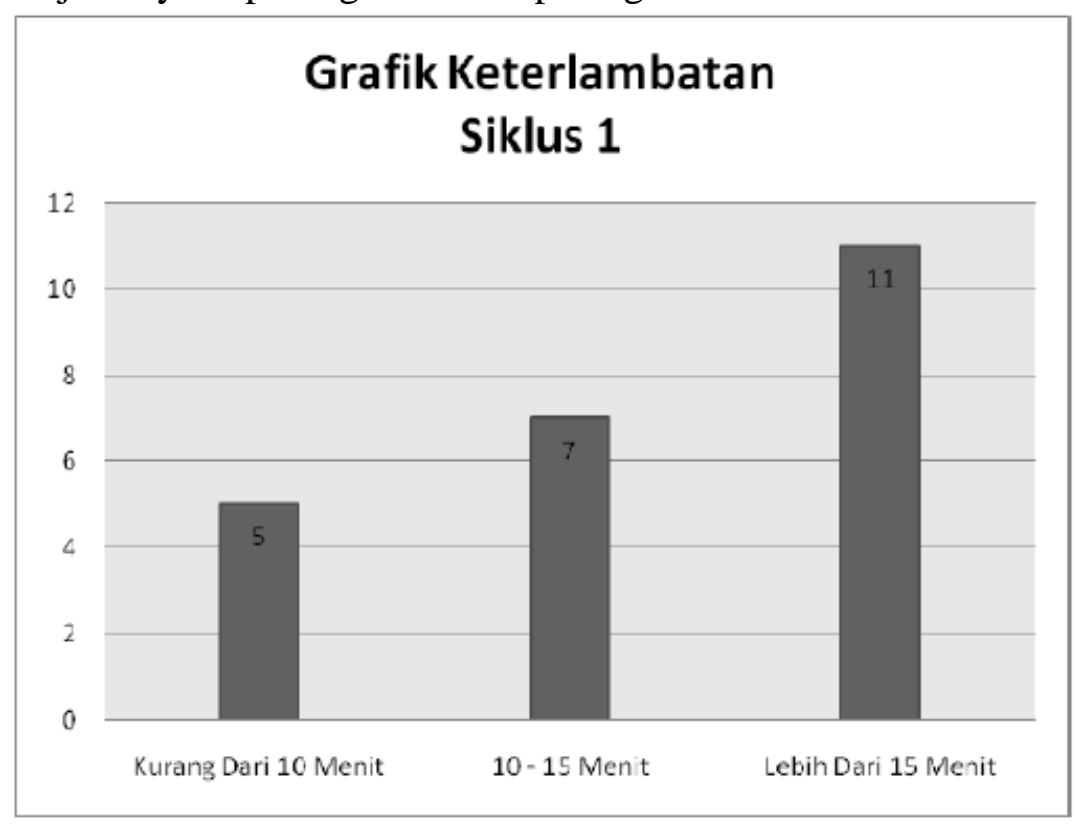

Grafik 1. Keterlambatan Guru Dalam Mengajar Siklus 1

Dari data diatas dapat ditarik kesimpulan bahwa tingkat keterlambatan guru masuk kelas lebih dari 15 menit pada proses kegiatan belajar mengajar masih tinggi yaitu 10 orang atau 45,46\%. Berdasarkan indicator yang telah ditetapkan bahwa keberhasilan tindakan ini adalah $75 \%$, atau bila $75 \%$ guru tidak terlambat lebih dari 10 menit. Pada siklus pertama ini guru yang tidak terlambat lebih dari 10 menit baru $22,73 \%$, jadi peneliti berkesimpulan harus diadakan penelitian atau tindakan lagi pada siklus berikutnya atau siklus kedua. 
Selanjutnya berdasarkan hasil pengamatan terhadap pelaksanaan RPP pada PBM, pengamatan (observasi) yang dilakukan pada siklus I maka diperoleh hasil penelitian disampaikan dalam bentuk tabel 2 berikut.

Tabel 2. Hasil Observasi Kedisiplinan Guru Siklus I

\begin{tabular}{|c|c|c|c|c|c|c|c|c|}
\hline \multirow{2}{*}{ No } & \multirow{2}{*}{$\begin{array}{l}\text { Poin } \\
\text { Kedisiplinan }\end{array}$} & \multicolumn{6}{|c|}{ Kategori } & \multirow{2}{*}{$\begin{array}{l}\text { Jumlah } \\
\text { Guru }\end{array}$} \\
\hline & & $\mathbf{A}$ & $\%$ & B & $\%$ & $\mathbf{C}$ & $\%$ & \\
\hline 1 & $\begin{array}{l}\text { Ketepatan } \\
\text { Waktu Mengajar }\end{array}$ & 10 & 22.73 & 12 & 27.27 & 22 & 50.00 & 44 \\
\hline 2 & $\begin{array}{l}\text { Kerapian } \\
\text { Seragam Guru }\end{array}$ & 15 & 34.09 & 13 & 29.55 & 16 & 36.36 & 44 \\
\hline 3 & $\begin{array}{l}\text { Kerajinan } \\
\text { Penyusunan RPP }\end{array}$ & 13 & 29.55 & 14 & 31.82 & 17 & 38.64 & 44 \\
\hline 4 & $\begin{array}{l}\text { Pelaksanaan } \\
\text { RPP pada PBM }\end{array}$ & 11 & 25.00 & 14 & 19.00 & 19 & 43.18 & 44 \\
\hline
\end{tabular}

Dari data di atas menunjukkan bahwa hasil observasi oleh peneliti di SMP Negeri 1 Kecamatan Payakumbuh cukup memuaskan dan hal ini akan berdampak buruk dalam kegiatan proses belajar mengajar di kelas. Oleh karena itu penulis melakukan kembali observasi di siklus I belum sesuai dikarenakan kedisiplinan sebagian besar guru berkategori $\mathrm{C}$.

\section{d. Refleksi Siklus I}

Hasil dari diskusi bersama kolabulator untuk mengadakan refleksi tindakan-tindakan yang telah dilakukan guru tentang upaya kesungguhan guru atau kelemahan-kelemahan selama pelaksanaan tindakan akan dijadikan dasar dalam membuat perbaikan perencanaan siklus kedua.

1) Hasil penelitian menunjukkan bahwa pada tindakan pada siklus I keterlaksanaan setiap aspek yang diteliti masih berkisar antara 60\%-70\%.

2) Sebagai refleksi setelah terjadi pelaksanaan kegiatan penelitian dalam proses belajar mengajar diperoleh informasi dari hasil pengamatan bahwa para guru di SMP Negeri 1 Kecamatan Payakumbuh masih kurang dalam memotivasi diri dan kedisiplinan selama pembelajaran berlangsung dan ini akan berdampak negatif bagi siswa baik untuk peningkatan prestasi belajar siswa maupun untuk meningkatkan motivasi belajar siswa.

Berdasarkan hasil refleksi dirumuskan bahwa perlu dilakukan beberapa hal sebagai tindak lanjut untuk meningkatkan keterlaksanaan aspek yang diteliti, yaitu (1) perlu keteladanan dan penegakan disiplin dari kepala sekolah dalam hal kehadiran tepat waktu, (2) perlu penyediaan sarana kegiatan belajar dalam hal kelengkapan administrasi guru, (3) perlu pemenuhan administrasi dan evaluasi kelas dalam hal meningkatkan durasi penyelesaian mengajar KBM di kelas, (4) perlu kegiatan remedial untuk meningkatkan pecapaian target KBM yang masih berkisar 60\%, (5) perlu diberikan reward dan punishment berkaitan dengan peningkatan kedisiplinan guru dalam mengajar. Dari hasil refleksi dapat diambil suatu kesimpulan bahwa perlu penerapan Reward dan Punishment yang lebih tegas lagi daripada siklus pertama.

\section{Siklus II}

\section{a. Perencanaan Siklus II}

Siklus kedua merupakan lanjutan dari pelaksanaan siklus pertama. Dalam membuat perencanaannya pun mengacu kepada hasil penelitian pada siklus pertama. Perencanaan yang dilakukan penelitian pada siklus kedua tidak berbeda 
dengan perencanaan pada siklus pertama. Pelaksanaan siklus kedua dilakukan untuk memperbaiki kekurangan-kekurangan yang ditemukan pada siklus kesatu.

\section{b. Tindakan Siklus II}

Siklus kedua dilaksanakan pada hari Senin tanggal 10 Juni 2019 yang dimulai pada pukul 07.30-08.40 WIB. Tempat pelaksanaan kegiatan di SMP Negeri 1 Kecamatan Payakumbuh. Dalam siklus kedua, kepala sekolah melaksanakan kegiatan reward and punishment kepada guru-guru dengan harapan agar guru semakin meningkatkan kedisiplinannya.

1) Menyebarkan lembar pengamatan kepada setiap Ketua Kelas atau Sekretaris kelas sebanyak 12 set, sesuai dengan banyaknya jumlah rombongan belajar di SMP Negeri 1 Kecamatan Payakumbuh sebanyak 12 rombongan belajar. Dalam lembar pengamatan itu, telah dibuat daftar guru yang mengajar dikelas itu setiap jam dan diberi kolom jam masuk kelas serta jam keluar kelas. Lembar pengamatan dapat dilihat pada lampiran.

2) Berkoordinasi dengan petugas piket yang setiap hari terdiri dari 2 orang petugas, yaitu dari guru yang tidak mempunyai jam mengajar pada hari itu dan satu orang dari tata usaha. Petugas piket akan mengedarkan daftar hadir guru dikelas yang telah dibuat agar dapat melihat tingkat kehadiran guru disetiap kelas dan disetiap pergantian jam pelajaran. Guru yang terlambat lebih dari 15 menit, dianggap tidak hadir dan diberi tanda silang.

3) Setelah selesai jam pelajaran, dilakukan rekapitulasi dari hasil pengamatan, baik dari guru piket, dari siswa maupun dari penulis. Kegiatan tersebut dilakukan terus setiap hari kepada setiap guru selama satu minggu (satu siklus) pada siklus kedua

\section{c. Observasi Siklus II}

Pengamatan atau observasi dilakukan oleh peneliti dengan menggunakan lembar observasi selama satu minggu (satu siklus), untuk semua guru yang berjumlah 44 orang. Pengamatan oleh peneliti meliputi :

1) Kehadiran guru dikelas

2) Tingkat keterlambatan guru masuk kelas

3) Waktu meninggalkan kelas setelah selesai pelajaran

4) Kerapian berseragam guru, dan kesiapan guru dalam memberikan materi ajar.

5) Kesiapan guru-guru untuk mentaati aturan tata tertib sekolah

6) Hasil akhir kerja

Peneliti juga melakukan penilaian dari hasil lembar observasi yang dibagikan kepada pengurus kelas untuk mengamati kehadiran guru dikelas. Dari hasil pengamatan serta rekap dari tingkat kehadiran guru dikelas pada proses belajar mengajar pada siklus kedua dapat dilihat pada tabel berikut :

Tabel 3. Rekapitulasi Tingkat Keterlambatan Guru Pada Kehadiran Di Kelas Siklus II

\begin{tabular}{|c|c|c|}
\hline \multicolumn{3}{|c|}{ Waktu Keterlambatan/Jumlah/Persentase } \\
\hline Kurang dari 10 menit & 10 menit s/d 15 menit & Lebih dari 15 menit \\
\hline 17 & 5 & 0 \\
\hline $77,27 \%$ & $22,73 \%$ & $0,00 \%$ \\
\hline
\end{tabular}

Dari hasil rekapitulasi tingkat keterlambatan guru dikelas pada proses pembelajaran diperoleh data, sebanyak 17 orang guru terlambat masuk kelas kurang dari 10 menit, 5 orang guru terlambat masuk kelas 10 menit sampai 
dengan 15 menit, dan tidak ada satu orangpun guru yang terlambat masuk kelas lebih dari 15 menit.

Untuk lebih jelasnya, tingkat keterlambatan guru masuk kelas pada proses belajar mengajar pada siklus kedua ini dapat digambarkan pada grafik dibawah ini:

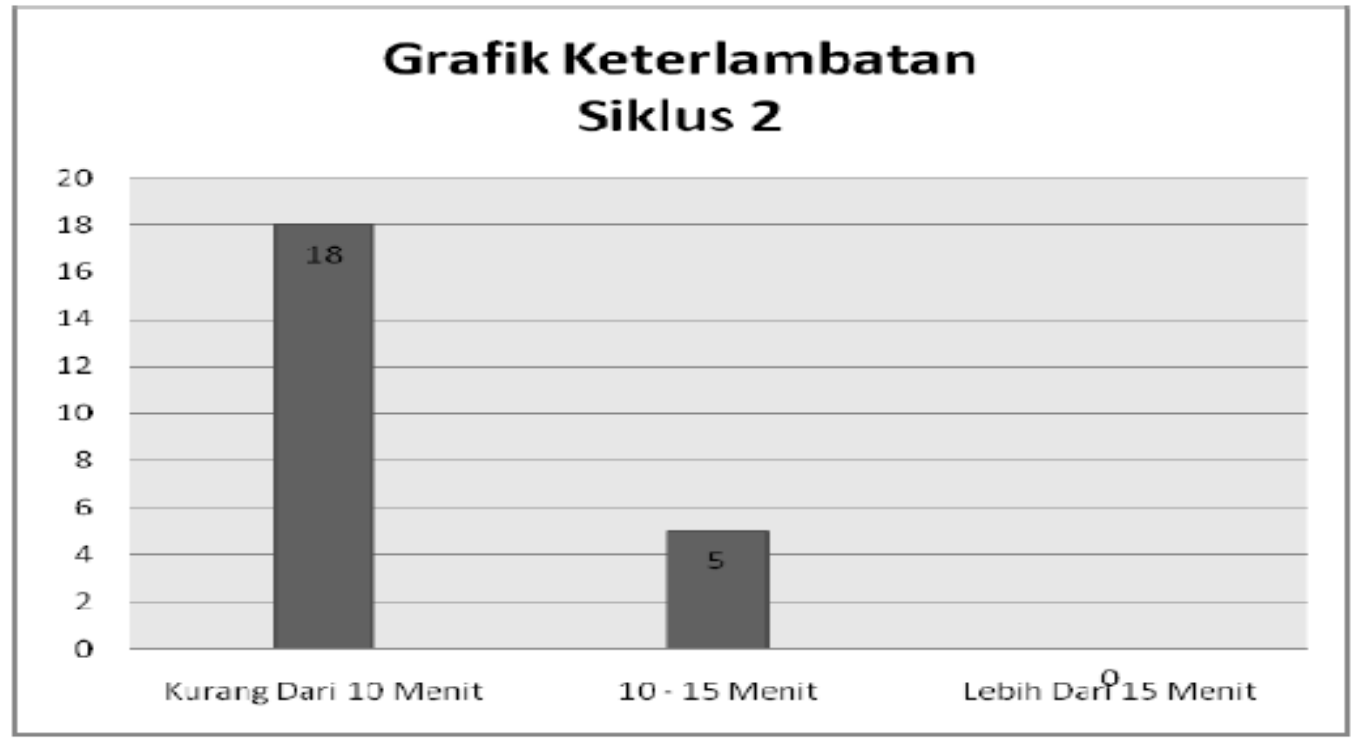

Grafik 2. Keterlambatan Guru Dalam Mengajar Siklus 2

Dari hasil observasi pada siklus pertama dan siklus kedua dapat dilihat ada penurunan tingkat keterlambatan guru dikelas pada kegiatan belajar mengajar, atau terdapat peningkatan kehadiran guru dikelas.

Selanjutnya berdasarkan hasil pengamatan terhadap pelaksanaan RPP pada PBM, pengamatan (observasi) yang dilakukan pada siklus I maka diperoleh hasil penelitian disampaikan dalam bentuk tabel 4 berikut.

Tabel 4. Hasil Observasi Kedisiplinan Guru Siklus II

\begin{tabular}{|l|l|l|l|l|l|c|l|c|}
\hline \multirow{2}{*}{ No } & Poin & \multicolumn{3}{|l|}{ Kategori } & \multicolumn{1}{l|}{$\begin{array}{l}\text { Jumlah } \\
\text { Kuru }\end{array}$} \\
\cline { 2 - 8 } & Kedisiplinan & A & \% & B & \% & C & \% & 44 \\
& $\begin{array}{l}\text { Ketepatan } \\
\text { Waktu } \\
\text { Mengajar }\end{array}$ & 21 & 47.73 & 20 & 45.45 & 3 & 6.82 & 44 \\
\hline 2 & $\begin{array}{l}\text { Kerapian } \\
\text { Seragam Guru }\end{array}$ & 25 & 56.82 & 18 & 40.91 & 1 & 2.27 & 44 \\
\hline 3 & $\begin{array}{l}\text { Kerajinan } \\
\text { Penyusunan } \\
\text { RPP }\end{array}$ & 26 & 59.09 & 18 & 40.91 & 0 & 0.00 & 44 \\
\hline 4 & $\begin{array}{l}\text { Pelaksanaan } \\
\text { RPP pada PBM }\end{array}$ & 25 & 56.82 & 19 & 19.00 & 0 & 0.00 & 44 \\
\hline
\end{tabular}

Dari data di atas menunjukkan bahwa hasil observasi oleh peneliti di SMP Negeri 1 Kecamatan Payakumbuh memuaskan dan hal ini telah berdampak baik dalam kegiatan proses belajar mengajar di kelas. Oleh karena itu penulis menyatakan observasi di siklus II telah memuaskan dan berdampak baik terhadap 
PBM. Oleh karena itu penulis memberikan penghargaan nilai positif A bagi guruguru sebagai sampel kegiatan penelitian tindakan sekolah dalam pembinaan kedisiplinan selama KBM di SMP Negeri 1 Kecamatan Payakumbuh.

\section{d. Refleksi Siklus II}

Setelah selesai pelaksanaan tindakan pada siklus kedua maka diadakan refleksi mengenai kelemahan atau kekurangan dari pelaksanaan tindakan pada siklus kedua tersebut.

1. Dari hasil observasi dan data yang diperoleh, peneliti mengambil kesimpulan bahwa tindakan yang dilaksanakan pada siklus kedua dinyatakan berhasil, karena terdapat $77,27 \%$ guru yang terlambat kurang dari 10 menit, atau melebihi target yang telah ditentukan sebesar 75\%.

2. Sebagai refleksi setelah terjadi pelaksanaan kegiatan penelitian dalam proses belajar mengajar diperoleh informasi dari hasil pengamatan bahwa para guru di SMP Negeri 1 Kecamatan Payakumbuh telah baik dalam memotivasi diri dan kompetensi

Hal mungkin disebabkan karena adanya komitmen esensi sumber daya manusia yang profesional. Melalui metode reward dan punishment yang dalam penelitian ini dapat meningkatkan kedisiplinan guru.

\section{Pembahasan}

Penelitian tentang upaya kepala sekolah dalam meningkatkan kedisiplinan guru dalam kehadiran mengajar melalui reward and punishment di SMP Negeri 1 Kecamatan Payakumbuh Semester 2 Tahun Pelajaran 2018/2019 dilaksanakan dalam dua siklus dengan menerapkan inspeksi dan kunjungan dinas dengan ciri sebagai berikut :

1. Mengumpulkan guru dalam satu ruangan

2. Peneliti mendatangkan narasumber untuk memberikan informasi tentang motivasi kedisilinan sebagai peningkatan etos kerja guru dalam mengajar di kelas.

3. Memberikan binaan secara klasikal

Penelitian dapat berlangsung dengan baik karena situasi berlangsung terbuka dan kolaboratif. Dengan menerapkan kedisiplinan dalam proses belajar mengajar akan dapat berlangsung dengan baik dan menyenangkan. Dengan penerapan reward and punishment dapat menumbuhkan minat, sikap dan kemauan guru untuk melaksanakan tugasnya seperti halnya menyusun tes hasil belajar; menyusun RPP, ikut menjaga kebersihan diri dan lingkungan sekitar sekolah dan lain sebagainya. Di sekolah mungkin dibutuhkan penghargaan untuk prestasi guru yang dicapai.

Sangsi dan ganjaran adalah merupakan bentuk hukuman dan pujian yang diberikan seseorang kepada orang lain disebabkan adanya pelanggaran terhadap peraturan dan tata tertib ataupun penghargaan atas prestasi kerja yang diperoleh. Bagi guru penghargaan memang sesuatu yang relatif dibutuhkan oleh mereka, agar apa yang dilakukannya dapat memberikan motivasi yang tinggi untuk selalu berusaha dengan baik dalam melaksanakan tugas dan kewajibannya sehari-hari Dalam Undang-undang Sistem Pendidikan Nasional, Pemerintahan memberikan penghargaan kepada tenaga pendidikan termasuk para guru yang baik dalam melaksanakan tugasnya. Sesuai dengan peraturan pemerintahan RI Nomor 38 Tahun 1992 tentang tenaga kependidikan pada pasal 59 ayat 1 yang berbunyi : 
Penghargaan diberikan kepada tenaga kependidikan pada satuan pendidikan baik dijalur pendidikan sekol;ah maupun diluar jalur pendidikan sekolah atas dasar prestasi kerja, pengabdian, kesetiaan pada lembaga, berjasa terhadap Negara, karya luar biasa atau tewas dalam melaksanakan tugas.

Dalam tata tertib sekolah ada pula sangsi atau hukuman bagi yang melanggar. Kepala madrasah sebagai pemimpin di sekolah tentu saja memberikan hukuman kepada guru yang melanggar peraturan dan tata tertib tersebut. Begitu pula sebaliknya ia harus memberikan pujian ataupun ganjaran kepada guru yang memiliki prestasi kerja yang baik. Sangsi dan ganjaran yang diberikan bisa dalam bentuk arahan, bimbingan, teguran. Pemberian sangsi dan ganjaran tersebut dimaksudkan agar para guru dapat termotivasi untuk melakukan tugas dan kewajibannya dengan baik dan tidak melanggar disiplin sekolah yang sudah ditetapkan. Dengan adanya para guru tidak melanggar disiplin maka terwujudlah disiplin yang baik di sekolah itu.

Pada awalnya guru-guru merasa tidak siap terhadap inspeksi dan kunjungan dinas untuk pembinaan kedidiplinan, dengan alasan terbatasnya waktu dan sulitnya kesadaran secara mandiri terhadap arti pentingnya disiplin. Setelah peneliti melalui pembinaan dan pengarahan tentang tujuan dan maksud pelaksanaan kegiatan penelitian tindakan sekolah dengan tema kedisiplinan selama proses belajar mengajar, maka para guru di SMP Negeri 1 Kecamatan Payakumbuh setuju dan mau diajak secara kolaboratif sebagai subjek penelitian guna mengimplementasikan aspek nilai kedisiplinan menjadi satu yang sangat penting.

Selama penelitian berlangsung, bagi para guru di SMP Negeri 1 Kecamatan Payakumbuh sangat respek terhadap pelaksanaan kegiatan penelitian tindakan sekolah ini terlebih pada saat putaran kedua dilaksanakan, alhasil banyak peningkatan mutu dan etos kinerja guru dalam menjaga dan melaksanakan rasa kedisiplinan diri secara mandiri untuk menjaga kebersihan dan kerapian serta menyusun dan melaksanakan RPP dengan serius. Hal ini akan menjadi satu tolak ukur keberhasilan mencerdaskan pendidikan di sekolah menengah pertama.

\section{KESIMPULAN DAN SARAN Kesimpulan}

Berdasarkan analisis data, dari penelitian ini dapat ditarik kesimpulan bahwa penerapan Reward dan Punishment efektif untuk meningkatkan disiplin kehadiran guru dikelas pada kegiatan belajar mengajar. Data yang diperoleh menunjukan bahwa setelah diadakan penerapan tindakan berupa Reward dan Punishment, guru yang terlambat lebih dari 15 menit adalah 0, dan guru yang terlambat kurang dari 10 menit sebanyak 17 orang guru. Penerapan Reward dan Punishment dapat meningkat disiplin guru hadir di dalam kelas pada kegiatan belajar mengajar di SMP Negeri 1 Kecamatan Payakumbuh. Hal ini dapat dilihat dari hasil pengamatan pada lembaran observasi dan grafik pada tiap-tiap siklus, bahwa adanya peningkatan yang signifikan terhadap kedisiplinan kinerja guruguru dalam pembelajaran di SMP Negeri 1 Kecamatan Payakumbuh dengan penerapan reward and punishment. 


\section{Saran}

\section{Bagi Pihak Sekolah}

Pihak sekolah dalam hal ini kepala sekolah harus mendukung dan memberikan kemudahan terhadap kegiatan reward and punishment sebagai salah cara mengembangkan pembelajaran yang lebih terarah dan bermakna.

\section{Bagi Guru}

a. Dalam memberikan solusi agar kedisiplinan guru meningkat selain reward dan punishment juga adanya keteladanan dan perhatian dari pihak-pihak stakeholder untuk melengkapi sarana prasarana mengajar, serta biaya untuk mendukung kesejahteraan guru. Diterapkannya kegiatan pelatihan atau diklat.

b. Untuk menjadi guru yang baik dan profesional harus bersedia mengikuti kegiatan-kegiatan pendidikan dan pelatihan baik melalui MGMP atau kegiatan yang dapat mengikuti perkembangan kemajuan ilmu pengetahuan, teknologi serta mempertebal keimanan dan ketaqwaan terhadap Tuhan Yang Maha Esa

\section{Bagi Pengembang Penelitian}

Mengingat keterbatasan dalam penelitian ini, maka perlu diadakan penelitian lebih lanjut untuk mengetahui kontribusi implementasi reward and punishment pada jenjang dan sekolah yang berbeda.

\section{DAFTAR PUSTAKA}

Ahmadi, Abu \& Uhbiyati, Nur. 1991. Ilmu Pendidikan. Jakarta: Rineka Cipta.

Dahar, Ratna Wilis. 2011. Teori-teori Belajar dan Pembelajaran, Jakarta : Erlangga

Imron, Ali. 2012. Manajemen Peserta Didik Berbasis Sekolah. Jakarta: Bumi

Aksara

Masykur, Arif Rahman. 2011. Kesalahan-Kesalahan Fatal Paling Sering Dilakukan Guru Dalam Kegiatan Belajar Mengajar. Jogyakarta: Diva Press.

Prijodarminto, Soegeng. 1993. Disiplin Kiat Menuju Sukses. PradnyaParamita: Jakarta

Sardiman A.M. 2012. Interaksi dan Motivasi Belajar Mengajar, Jakarta : PT. Raja Grafindo Persada

Wantah, Maria J. 2005. Pengembangan Disiplin dan Pembentukan Moral pada Anak Usia Dini. Jakarta: Departemen Pendidikan Nasional 